\title{
unindra
}

Universitas Indraprasta PGRI

Address: Jl. Nangka No. 58 C (TB. Simatupang), Kel. Tanjung Barat, Kec. Jagakarsa, Jakarta Selatan 12530, Indonesia. +62 (021)

7818718 - 78835283; url: www.unindra.ac.id; cultural.syndrome@unindra.ac.id

\section{Designing of Comic Strip as Learning Media in \\ Future Tense Material}

\author{
Catur Sunu Wijayanto ${ }^{1}$, Fitria Iswari ${ }^{2}$, Dian \\ Handayani $^{3}$
}

Departement of Visual Communication

Design Universitas Indraprasta PGRI ${ }^{123}$

Correspondence regarding this article should be addressed to:

Fitria Iswari,fitriaiswari@gmail.com

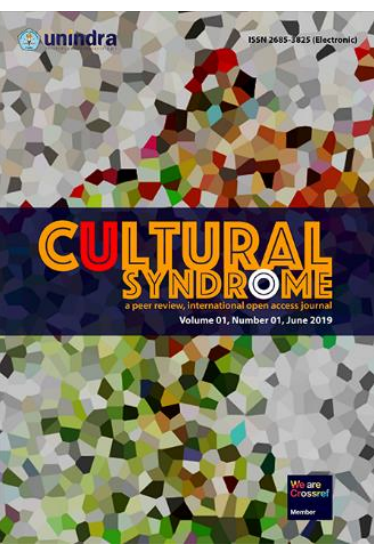

\section{Cultural Syndrome}

a peer review, internasional open access journal e-ISSN: 2685-3825

Editor: iD M.I.Qeis

\section{Article History}

Received : 30-11-2020

Revised : 28-12-2021

https://journal.unindra.ac.id/index.php/cusy/ about/submissions\#authorGuidelines

\section{How to cite this article (MLA 8th)}

Wijayanto, Catur Sunu, Fitria Iswari, and Dian Handayani. "Designing of Comic Strip as Learning Media in Future Tense Material." Cultural Syndrome, Vol.2, No.2, 2020, pp. 150-161., http://dx.doi.org/10.30998/cs.v2i2.501

The readers can link to article via http://dx.doi.org/10.30998/cs.v2i2.501

Universitas Indraprasta PGRI (as Publisher) makes every effort to ensure the accuracy of all the information (the "Content") contained in the publications. However, we make no representations or warranties whatsoever as to the accuracy, completeness, or suitability for any purpose of the Content. Any opinions and views expressed in this publication are the opinions and views of the authors, and are not the views of or endorsed by Universitas Indraprasta PGRI. The accuracy of the Content should not be relied upon and should be independently verified with primary sources of information.

\section{(c) (i) (-)}

This work is licensed under a Creative Commons Attribution-NonCommercial 4.0 International License.

Copyright by Catur Sunu Wijayanto, Fitria Iswari, Dian Handayani (2020)

The authors whose names are listed in this manuscript declared that they have NO affiliations with or involvement in any organization or entity with any financial interest (such as honoraria; educational grants; participation in speakers' bureaus; membership, employment, consultancies, stock ownership, or other equity interest; and expert testimony or patent-licensing arrangements), or non-financial interest (such as personal or professional relationships, affiliations, knowledge or beliefs) in the subject matter or materials discussed in this manuscript. This statement is signed by all the authors to indicate agreement that the all information in this article is true and correct 


\title{
Designing of Comic Strip as Learning Media in Future Tense Material
}

\author{
Catur Sunu Wijayanto ${ }^{1}$, Fitria Iswari ${ }^{2}$, Dian Handayani ${ }^{3}$ \\ Departement of Visual Communication Design \\ Universitas Indraprasta PGRI
}

\begin{abstract}
.
In Indonesia, English is one of language which is learnt from elementary school University level. College students from Visual communication design program in first semester will get future tense material in English 1. In future tenses there 2 formulas which are used based on the functional of the sentence, and it is difficult for student in differentiating the formulas, Media has important role in teaching learning process. Comic strip is familiar for milenilal. Based on the background writer decide to design a comic strip as learning media. The designing of comic strip is aim to give new or alternative media in teaching learning process. This comic strip covers future tense material that includes "to be going to" and "will" form. This research used qualitative method. The results of this research is designing of a comic strip in 8 panels that is written in English and covered future tense material which give illustration how the two formulas of future tenses are used. The typography is comic sans MS, the main characters are three girls of Senior High School student. Comic strip is made in tradiotional/ manual process by drawing use pencil then through digitally process for the finishing. The colour of the comic strip uses calm colours and are dominated grey according to senior high school uniform colour, in order to make the reader feel the comfortable. The conclusion shows comic strip could be an alternative media in learning process.
\end{abstract}

Keywords: Comic strip, Future tenses, Learning Media

Correspondence author: Fitria Iswari,fitriaiswari@gmail.com, Jakarta and Indonesia 


\section{Introduction}

English in Indonesia as a foreign language contributes to education in Indonesia. English subjects is given from elementary school to college level. In the curriculum at the Universitas Indraprsata PGRI study program Visual Communication Design (DKV). English material is studied in semesters 1 and 2. In order to make students are able to master English well. In English course 1 students will be given grammar material in the form of various kinds of tenses, and they must understand it. From the observations during teaching, students often find difficulties with the future tense material in the use of will and to be going to, because they hve different pattern but same purpose taht is show the situation that will be in the next.

In teaching learning process we do not only need the powerful teacher but also interestingmedia to make the process easier. It is undeniable that today technology development gives challenge for educators, both lecturers and teachers in choosing learning media that is suitable for the millennial generation. Lecturers as facilitators of students will always try to give their best in the learning process in order to achieve goals or objectives in education. The functions and purpose of education as stated in Law Number 20 of 2003 Article 3 that the purpose of education can be achieved by the participation of educators in supporting the implementation of excellent education. In the learning process, the media has an important and influential role. Seems the previous study, The article explain The product developed can increase students' reading motivation seen from a significance of 0.0 and positive ranks is better than negative ranks (Maghfirah and Herowati), Moreover Ulva stated that in general students like comic developing because comic can be very helpful when learning process . for further information, the research conducted by Sasti Karmiani in an article entitled The Use of Comic Media in English to Improve Reading Comprehension Ability in Class VIII of SMPN 3 Teluk Kuantan (Hidayah and Ulva). It shows that there is an increase in the students' reading comprehension ability which increases to $75.23(80.95 \%)$ which is included in the good criteria. This shows that the use of the right media can give the best results.

Based on this description above, the writer will design a comic strip. The choosing of comic strip as learning media is based on the Visual Communication design students, most of them visual or picture like comic strip. The concept uses current designs, colors and typography based on its segmentation which is teenagers. Thus object will be interested in studying the future tense. The problem is how to design comic strips as students leaning media on future tense material. The object of designing of comic strip is college students, who in the reality, need learning media that suits their needs in understanding tenses, especially future tense material. The purpose of designing comic strips as a learning media for visual communication design students is to make them are able to master the future tense material well, making it easier in the learning process, thus it makes the teaching and learning process more enjoyable and efficient 


\section{Methods}

This study used qualitative methods with descriptive approach which the data collection are obtained from some resources, the first Observation, The writer observed the students' mistake in answering the question of future tense. The data can help writer to choose the appropriate words or sentences that are used in comic strip. The second through Interviewed, Writer interviewed to some of students from 4 classes. It was done in order to obtain information about the difficulty and the attractive learning media in learning tenses. This information will help writer in designing process the comic strip. The third Study literature. Search sources that is related to this study from some articles or researches

There are some step in doing this study, Moleong said that study design is an effort to plan and decide in every possibility that is needed in a qualitative study that consists of some steps pre observation, do observation, and analysis data. There are some step in designing the comic strip, here are:

1. Preparation.

In here writer prepare the material, interview list to students, and the documentation or a note to record the activity in the classroom.

2. Colleting the data :

The writer collect the data about the object to decide the theme, character, typography, color that is suitable with students reading.

3. Data analysis :

Re-check the component of comic strip and ask to object of their response about the comic strip was made.

\section{Result and Discussion}

A comic strip is a picture or series of pictures that contain of a story (Arjuna). generally comics consist of three to six panels or more. The content of it can be humor, jokes or serious stories and be interesting to be listened until the story ends. Comic means pictures, and symbols are side by side in a certain order, to convey information or achieve aesthetic responses from the reader (McCloud and Manning). Based on the explanation from experts, comic strips are media that contain of simple picture and written which consists of 3 or 6 panels in order to convey information in the learning process

Media are all forms of communication tools that can be used to convey messages or information from sources in order to stimulate the thoughts, feelings, interests and attention of the recipient (Dhieni et al.). Learning media is a vehicle of messages from the teacher and are going to be forwarded to the recipient (Zaman). From this description, it can be concluded that learning media is a tool in the learning process in conveying messages in order to convey the information. 
There are some characteristic of fine media that must be considered in the selection of learning media, the criteria that should be considered in choosing learning media are as follows (Azhar):

1. Learning media should carry the objectives that is suitable to it, and referring to one or a combination of cognitive, affective, and psychomotor domains.

2. Learning media are appropriate to support the lessons that have facts, concepts, principles, or generalizations.

3. Learning media are practical, flexible, and durable.

4. The teacher must be skilled and able to use it in the learning process.

5. Effective and appropriate for target grouping.

6. Visual technical quality must meet certain technical requirements.

Moreover Genap explain Learning media can enhance the learning process, hoping that the learning outcomes will be increase. There are several benefits that can be obtained by using learning media, namely as follows (uwanto):

1. Teaching will attract students' attention so that it can foster motivation to learn.

2. The meaning of teaching materials will be clearer so that it can be better understood by students, and enable students to better master teaching objectives;

3. Teaching methods will be more varied, not merely verbal communication by the teacher, so that students do not get bored and teachers do not run out of energy;

4. Students do more learning activities, because they don't only hear the teacher's description, but also other activities such as observing, doing, demonstrating, and so on.

From the explanation about the media, in reality both students and teacher need improvement in learning media, in order to obtain the better objectives in learning process. The learning media must not expensive and shopisticated. The comic strip print can be an alternative handed learning media that is atrractive and affordable. However, it is not only interesting that the comic strip function if it is not controlled by the lecturer, students will be enjoyed the reading comic strip without notice the information in it. As expressed by (Rohani) states that the weakness of comic media is that it makes students fall asleep with reading comics so that they forget about textbooks if they don't get guidance from the teacher. In this learning activity, the lecturer pays attention to students so they are not complacent in reading comic strips.

In learning English, tenses is part of Grammar. Tenses is a linguistic concept which have a verb and express the time in situation (Reed and Cappelle). It means where the actions in time which indicates events that are happening. Two patterns in future tense are "will" and "to be going to" that have same meaning to show the situation / event that will be happen. In this comic strips, it will be designed by using 2 sentence patterns, will and be going based on its' function. Be going to state the event that will occur and it has been decided before (prior plan), and to state the events that are caused by events that indicate what will happen next. It is shown in "my family and I are going to go Bandung to spend our holiday, and how about you Nusaibah?". It has pattern "S + be (am , is, are) + going to + infinitive+ Object/ Compliment". While "will "is used to state the incident or event that will come and decide on that incident while speaking or state 
the event that will definitely happen. Here, speaker predict the event that will occur. It states in "yes ... and if we are late, He will be angry to us ... common". Will has pattern "S+ will+ infinitive + Object /Compliment"

The purpose of designing the comic strip is to help the target audience to understand the future tense more easily, especially in using of will and going to in a sentence through emphasizing the meaning and purpose in every conversation which is made. The creative strategy is by making a comic strip which is only 1 page that consists of 8 panels whose the story is related among panels, and there are sentences that distinguish the use of will and $t$ be going to. This comic strip is printed on A4 laminating carton board, this is to make it easier to carry, read, and use by students in the classroom.

The comic strip carries the teenagers' school life as a theme. The setting is the teenagers are chatting each other during break time in the canteen. The topic was taken is very general that, namely around vacation plans, the food being eaten, and the lecturers. The language style used is a non-formal language which is used in daily activity, but uses correct grammar. Then the words are put into word balloons, which are visualizations of the comic characters' dialogue, which are combined in the picture in a panel.

\section{Process of Designing the Comic Strip}

The beginning step of the process in producing the comic strip is making the picture manually used pencil as a sketch, then writer color the sketch by using Adobe illustrator and Photoshop program. The figure 1 and 2 are the sketch of the character. The first figure is sketch of the main three characters that are made manually use the pencil, and the second figure the finishing by using digitally process.

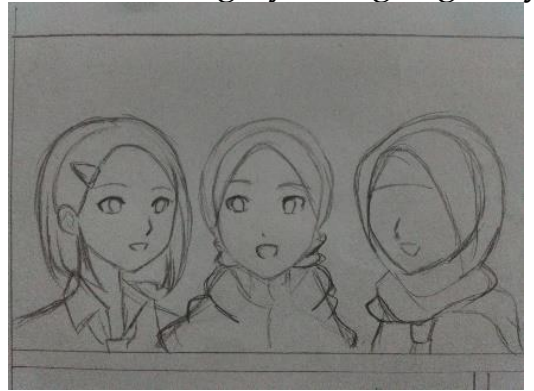

Fig. 1 Sketch of the character was made manually process

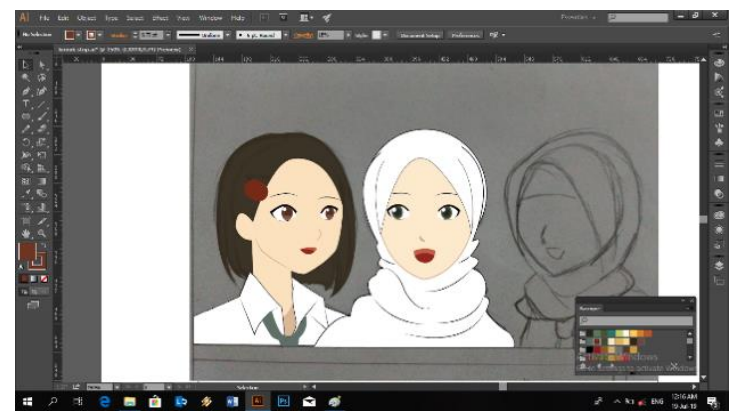

Fig.2 Sketch of the character was made digitally process 


\section{The characteristic of the target audience}

Target audiences of the designing of this comic strip are:

1. All Indonesia Geographic, this comic strip is used by almost students in Indonesia, because it is written in English, and English is one of the subject that is learnt in Indonesia, and almost in every level in Education is learnt English Especially tenses.

2. Age demographic : 15-25 years old

3. Gender : Women and Men.

4. Education : Junior, and Senior high school, college student and general. Because of the fiture tense is talking about tenses where tenses is used in oral and written language, so the comic strip can be used to teenage and general.

\section{The content of the story.}

Comic trip is written in English by using future tenses in some dialogues that is used by character.

Mia , Adreena, and Nusaibah who are Senior high school students are in conversation during a break time at the canteen school.

Mia : where are you going to go during the holiday next week? I am going to go Puncak Bogor

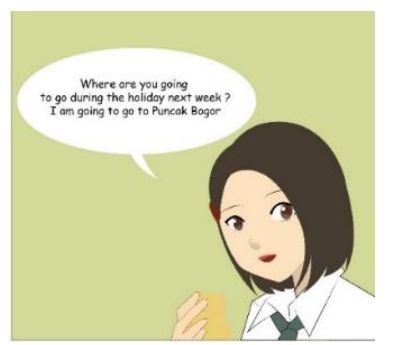

Fig. 3. Future tense of"to be going to " pattern.

In figure 1 mia is asking adreena about her friends planning to spend the next holiday. This sentence are written in future tense form with to be going to pattern. Because the situation has not happen yet, and they can make plan long time before the holiday come.

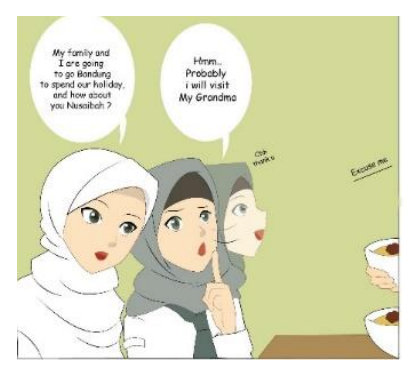

Fig. 4. Future tense of" to be going to " and "wil" pattern

Adreena : : my family and I are going to go Bandung to spend our holiday, and how about you Nusaibah?

Nusaibah $\quad$ : hhhmmm, probably I will visit my grandma. Well let's eat the noodle. Can you pas the chili sauce? 
The figure 4 shows that both character use the 2 different pattern. Adreena uses the " to be going to" pattern, whereas Nusaibah is speak in "will" pattern . Adreena uses the to be going to because She is sure and have decided the plan to go to Bandung. Nusaibah feels uncertainty, so she uses probably and will pattern, because She just predict the event that will be happened next without making plan before.

Mia : : be careful, it will make you spiciness.

Nusaibah : don't worry I like spicy food. I am going to eat with my noodle.

Krinnngg( the bell is ringing)

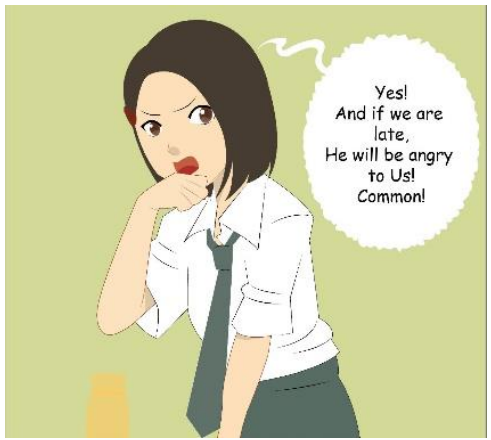

Fig. 5. Future tense of "wil" pattern

Adreena : common hurry up.. We are going to study English, and the teacher is Mr. Harun.

Mia : ya... and if we are late, He will be angry to Us... common

In Figure 5 . Mia is speaking by using "will" pattern, because mia just predict if ther are late. The teacher Mr. harun will be angry, the fact is mia doesn't surely know what will happen to Mr. harun if they come late.

From the conversation above the character is talking about the Holiday that means a plan that hasn't happen yet and the sentence need future tense in here. Some of future tense sentences of "to be going to" pattern are used when it talking about planning, and "will" pattern is used to predict the event that will occur, and the comic strip conveys both "will" pattern and " to be going to" pattern. It would be make easier to understand because the explanation is added illustration to help students to understand the material.

\section{Description of the character:}

The main characters are Mia, Adreena, and Nusaibah. They are Senior High School student who involve each other in a conversation in canteen at break time. In every conversation contain future tenses. The character use senior high school uniform in order to make the reader (students) feels the character is close to them whom is the students too. There is no special character, because it has limited panels, here are some personality traits of the character:

Mia : the girl whose the short straight hair, always looks fashionable, and likes to spend spare time to take holiday.

Adreena : The girls who is wearing white hijab, is friendly and the smartest in her class. 
Nusaibah : The girl who is wearing grey hijab, is friendly, the most careless among them, but she has kind heart.

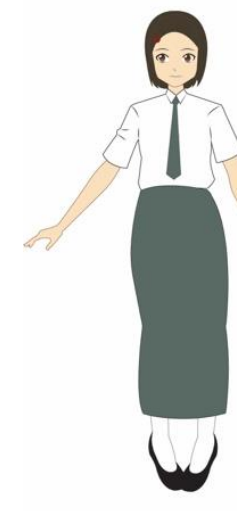

Mia

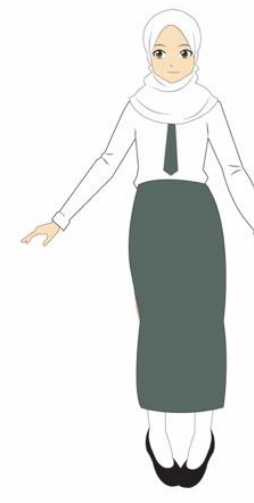

Adreena

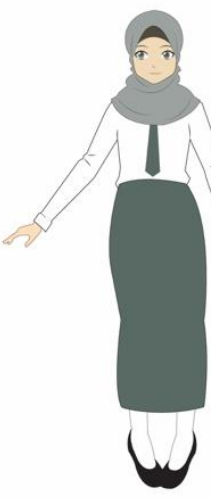

Nusaibah

Fig. 6 the main characters

The setting of time and place of this story are at the canteen school during the break time, and take only one place as the setting of place, because it is the short story Design layout elements towards a field in a particular media to support the concept or message that it are carried. This is used by visual communication design to organize space (Rustan). Each medium has a different layout, for example in comics. Layout in comics means the placment of panels in one image area. Panel order, panel size, text placement, and the way to read the dialog, are all included in the comic layout. The layout style used is an 8-panel comic strip, with dialogue that is written in word bubbles, in a rightleft-right panel sequence in a diagonal direction. The media used is A4 size paper divided by 8 panels.

\section{Color composition}

This comic strip use calm color tone, and white color in word bubble. Color is one of important thing in comic strip, (Mc Cloud.S) explained that there are some functions in color using, they are:

1. Color express mood

2. Color adds deepness impression

3. Color as sensation

4. Color as environment

5. Color as color

This comic strip used some calm color for the content. The color of the title use black color. The detailed of color composition will be explained by the table below: 
Table 1. The composition of the color in comic strip

\begin{tabular}{|c|c|c|}
\hline \multirow[t]{11}{*}{ WARNA } & CMYK & RGB \\
\hline & C $27 \%$ M $11 \%$ Y $72 \%$ K $0 \%$ & R 194 G 199 B 108 \\
\hline & C $60 \%$ M $63 \%$ Y $77 \%$ K $71 \%$ & R 48 G 39 B 25 \\
\hline & C $64 \%$ M $43 \%$ Y $54 \%$ K $24 \%$ & R 89 G 106 B 99 \\
\hline & C $34 \%$ M $89 \%$ Y $100 \%$ K $38 \%$ & R 120 G 43 B 25 \\
\hline & С $0 \%$ M $0 \%$ Y $0 \%$ К $0 \%$ & R 255 G 255 B 255 \\
\hline & C $61 \%$ M $43 \%$ Y $75 \%$ K $47 \%$ & R 71 G 81 B 55 \\
\hline & С $0 \%$ M $22 \%$ Y $73 \%$ K $0 \%$ & R 225 G 202 B 395 \\
\hline & C $15 \%$ M $100 \%$ Y $90 \%$ K $100 \%$ & R 190 G 30 B 45 \\
\hline & С $0 \%$ M $0 \%$ Y $0 \%$ K $100 \%$ & R 35 G 31 B 32 \\
\hline & C $26 \%$ M $51 \%$ Y $77 \%$ K $22 \%$ & R 157 G 111 B 67 \\
\hline
\end{tabular}

Comic strip has "Will or to be going to" as title which is placed on top right. The kind of typography is Comic sans MS. The text in the word bubble use Comic sans MS. The decision to use it because comic sans MS it is suitable for teenager and comic strip, and looks so relaxed. The finishing of this comic strip through digitally process, and will be printed at A4 laminating carton board.
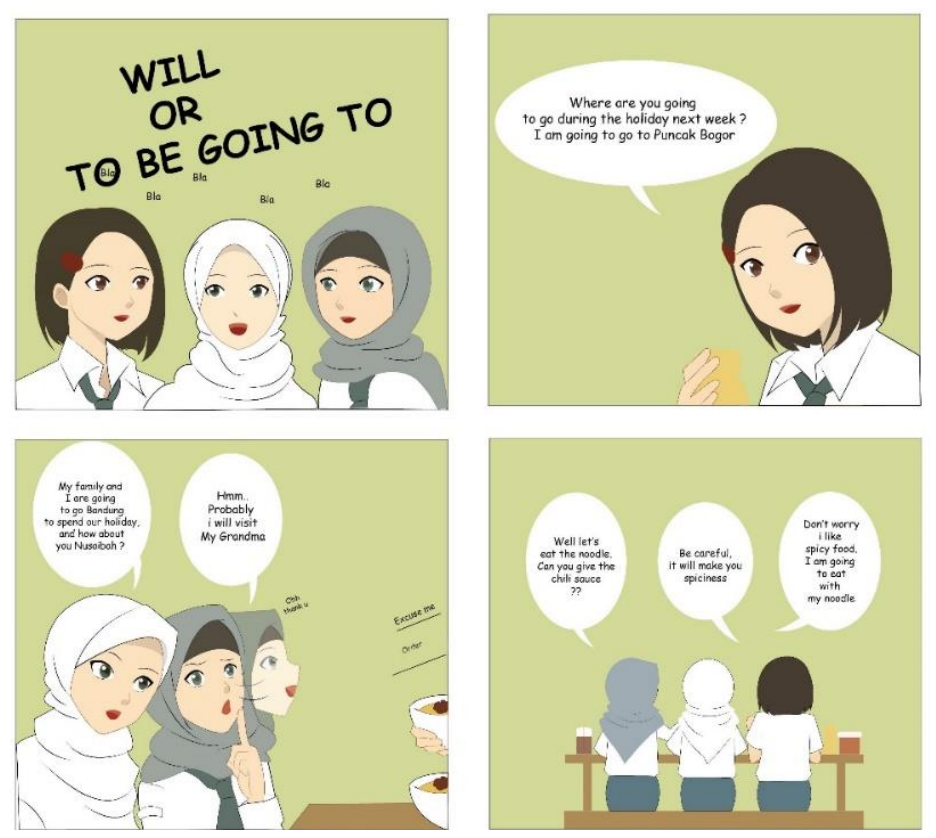

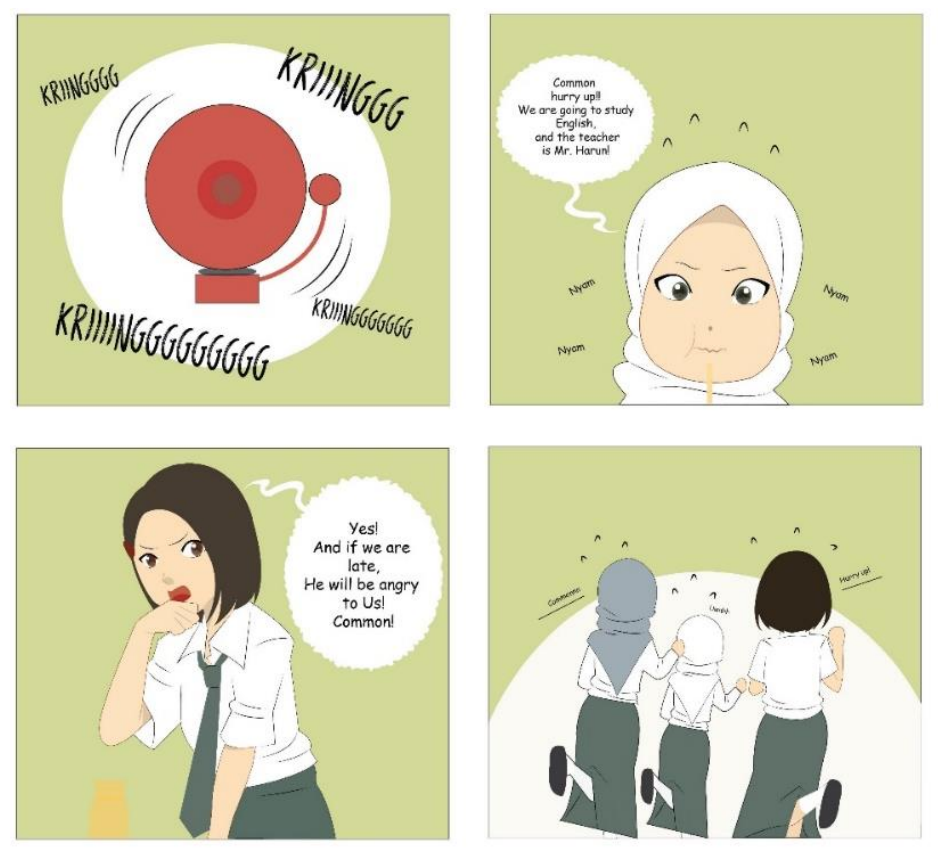

Fig 6. The comic strip

The figure 6 shows the full part of the comic strip that carries about future tense material. The comic use only three main cahactter because the limitation of place and time. The comic strip tells about how person decide the prior plan or the activities that has not been predicted yet, they just speak when they are speaking. This comic strip is eyecathing. If the media is interesting, so students could be improve their attention in leraning process ang gain all the knowledge that teachere sahred with.

\section{Conclusion}

English is the subject that is learnt until university education level. Tenses is learn from elementary school to university where students will find the various pattern of tenses, one of them is future tense which has two different pattern but has same purpose to say something in the future time. And some students found the difficult in differentiate the using of future tense pattern. Both teacher and students need improve or find other media to make teaching learning process is more efficient and enjoyable. Thus, designing the comic strip for future tense, is needed to make it simpler and efficient in teaching learning process. Based on the explanation above, it can be conclude that comic strip can be an alternative leaning media in milllenial. it uses color composition, illustration, layout, typography. The content uses comic sans Ms Font. Illustration uses senior high school student, the language is non formal that uses to in daily. The color composition uses calm color intend to make the reader comfort when they read it. The comic strip is designed in A4 size and 8 panels, and add word bubble that contain some expressions which uses present future tense. Students currently have 
their own gadgets or smartphones, and are also active on social media, such as Instagram, Twitter, Facebook, etc. In addition, visual communication design students are already familiar with comics, they often see it, for example comic strips on Instagram such as on the Juki account, comic books and so on, which discuss daily activities or simple comedies, they even often see it. Japanese comics' manga on the website. Thus it is not difficult to introduce comic strip to students. For the next research can improve the comic strip not only can be used din tenses material, but also in every aspect skills, (listening, speaking, reading, and writing) to make teaching learning process is easier.

\section{References}

Arjuna. "Komik Sebagai Media Pembelajaran." 14 Maret 2011 http://arjunabelajar.blogspot.com/2011/03/komik-sebagai-mediapembelajaran.html.

Azhar, Arsyad. Media Pembelajaran. PT Raja Grafindo Persada, 2011.

Dhieni, Nurbiana et al. "Modul Hakikat Perkembangan Bahasa Anak." Universitas Terbuka, 2014.

Hidayah, Nurul and Rifky Khumairo Ulva. "Pengembangan Media Pembelajaran Berbasis Komik Pada Mata Pelajaran Ilmu Pengetahuan Sosial Kelas Iv Mi Nurul Hidayah Roworejo Negerikaton Pesawaran." Terampil: Jurnal Pendidikan dan Pembelajaran Dasar, vol. 4, no. 1, 2017, pp. 34-46, doi:https://doi.org/10.24042/terampil.v4i1.1804.

Maghfirah, Firda and Herowati Herowati. "Pengembangan Media Komik Strip Sains "Pemanasan Global" Untuk Meningkatkan Motivasi Membaca Siswa Kelas Vii Smpn 2 Sumenep." LENSA (Lentera Sains): Jurnal Pendidikan IPA, vol. 7, no. 2, 2017, pp. 76-84, https:/jurnallensa.web.id/index.php/lensa/article/view/24.

McCloud, Scott and AD Manning. "Understanding Comics: The Invisible Art." IEEE Transactions on Professional Communications, vol. 41, no. 1, 1998, pp. 66-69.

Moleong, Lexy J. Metodologi Penelitian Kualitatif (Edisi Revisi). vol. 103, PT Remaja Rosdakarya, 2017.

Purwanto, Joko. "Penggunaan Replika "Tablet" Untuk Meningkatkan Kemampuan Menulis Short Message Dan Invitation Siswa Kelas Viii.C Mts Negeri Pundong Semester Genap Tahun Pelajaran 2014 / 2015." Contemporary Issues in English Linguistics, Literature, and Educations, UIN Sunan Kalijaga, 2016. 
Catur Sunu Wijayanto, Fitria Iswari, Dian Handayani (@ 2020)

Reed, Susan and Bert Cappelle. The Grammar of the English Tense System: A Comprehensive Analysis. De Gruyter, 2008.

Rohani, Ahmad. Media Instruksional Edukatif. Pt Rineka Cipta, 1997.

Rustan, Surianto. Layout, Dasar Dan Penerapannya, Cetakan Kedua. PT Gramedia Pustaka Utama, 2010.

Zaman, Badru. "Media Dan Sumber Belajar Tk." Esensi Sumber Belajar Dalam Pembelajaran Anak Usia Dini, edited by AH Hernawan and C Eliyawati, Universitas Terbuka, 2014, pp. 1-39. 